\title{
Influence of Fenugreek Flour (Trigonella foenum-graecum L.) Addition on the Technofunctional Properties of Dark Wheat Flour
}

\author{
Simona Maria Man (D), Adriana Păucean (D), Ioana Daniela Călian (D), Vlad Mureşan (D), \\ Maria Simona Chiş $\mathbb{D}^{D}$, Anamaria Pop $\mathbb{D}$, Andruţa Elena Mureşan $\mathbb{D}$, Monica Bota, \\ and Sevastiţa Muste $\mathbb{B}$
}

Department of Food Engineering, Faculty of Food Science and Technology,

University of Agricultural Sciences and Veterinary Medicine of Cluj-Napoca, 3-5, Mănăştur Street, 400372 Cluj-Napoca, Romania

Correspondence should be addressed to Adriana Păucean; adriana.paucean@usamvcluj.ro

Received 14 February 2019; Accepted 8 April 2019; Published 19 May 2019

Academic Editor: Luca Campone

Copyright ( 92019 Simona Maria Man et al. This is an open access article distributed under the Creative Commons Attribution License, which permits unrestricted use, distribution, and reproduction in any medium, provided the original work is properly cited.

Evaluation of fenugreek (Trigonella foenum-graecum L.) and dark wheat flour (type 1250) blends was performed, and the effect of fenugreek flour on the physicochemical, textural, microbiological, and sensory characteristics of wheat bread was studied. The fenugreek flour was blended with wheat flour at different levels: $2 \%, 5 \%$, and $8 \%$ for preparing bread samples. Even if a decrement of bread's crumb textural properties was recorded with fenugreek flour addition, the improved content in protein, ash, fiber, and antioxidant compounds was noticeable. The results of the sensory analysis indicated that the bread sample fortified with $2 \%$ and $5 \%$ fenugreek flour has the highest acceptability score. However, considering the health benefits of fenugreek bioactive compounds and their influence on overall quality of bread, it can be concluded that bread supplementation up to 5\% fenugreek flour is optimal.

\section{Introduction}

Fenugreek (Trigonella foenum-graecum) is a leguminous herb which belongs to the family Fabaceae. The plant seeds are used in Asia, Africa, and Mediterranean countries as one of the ingredients in daily diets [1] and in some domains such as medicine, nutrition, beverages, fragrances, cosmetics, or industrial purposes [2]. The pharmacological effects of fenugreek are antimicrobial, anticholesterolemic, carminative, febrifuge, laxative, restorative, uterine tonic, expectoral, galactogogue, anticarcinogenic, antiinflammatory, antiviral, antioxidant, hypotensive, etc. [3].

Fenugreek has a beneficial effect on cleansing the blood, and as a diaphoretic, it is able to bring on sweat and to help detox the body. The galactomannan-rich soluble fiber fraction of fenugreek seeds may be responsible for the antidiabetic activity. Clinical analysis showed that glycemic control was improved in a small study of patients with mild type-2 diabetes mellitus [4]. Moreover, mucilage, tannins, pectin, and hemicellulose inhibit bile salt absorption in the colon and hence facilitate low-density lipoprotein (LDL) cholesterol reduction in blood [5]. Phenolic compounds, for instance, through their antioxidant activity, are hypothesized to have cancer-suppressing ability [6]. The study conducted by Joglekar et al. [7] on the antioxidant activity of Aegle marmelos, fenugreek, and Coriander sativum showed that fenugreek is positioned on the second place regarding the phenolic content but on the first place if the flavonoids content is quantified; also, fenugreek showed the highest superoxide and free-radical scavenging activity among the studied species. Fenugreek contains protein $(\sim 30 \%)$, fiber $(\sim 30 \%)$, fat $(\sim 7.5 \%)$, available lysine $(5.7 \mathrm{~g} / 16 \mathrm{~g} \cdot \mathrm{N})$, vitamins, and minerals [8]. Flour fortified with $8-10 \%$ fenugreek fiber has been used to prepare bakery foods such as pizza, bread, muffins, and cakes with acceptable sensory properties [9]. Losso et al. [4] incorporated fenugreek in bread and 
demonstrated that fenugreek in food helps in reduction of blood sugar. Also, Hussein et al. [10] showed that fenugreek seed (raw, soaked, and germinated) significantly reduced total lipids, serum total cholesterol, and LDL cholesterol but nonsignificant changes in triglycerides and serum HDL-cholesterol were observed. Supplementation of basal diets with fenugreek leaves, seeds (dry and germinated), and wheat flour supplemented with germinated fenugreek powder at $5-10 \%$ levels increased the total proteins, fibers, iron, zinc, calcium, vitamin B2, carotene, vitamin $\mathrm{E}$, and vitamin C contents [11].

This study aimed to evaluate blends of fenugreek flour and wheat flour type 1250 in order to assess their suitability for bread production; for this purpose, the physicochemical, textural, microbiological, and sensory characteristics of fenugreek-supplemented bread were determined.

\section{Materials and Methods}

2.1. Procurement of Raw Materials. All the raw materials were purchased from the local market, from specialized stores. Fenugreek flour is obtained from India. A commercial wheat flour type 1250 , with $13.8 \%$ moisture and $28.3 \%$ gluten content was used. The fenugreek flour (FF) was blended with wheat flour type 1250 in different portions (2\%, $5 \%$, and $8 \%$ ) for producing wheat-fenugreek bread.

\subsection{Proximate Composition Analysis of the Flours and Breads.} The chemical characteristics were carried out according to AACC Approved Methods [12]. Moisture (44-15.02), lipids (30-25.01), ash (08-01.01), crude fiber (32-07.01), and protein were measured using the Kjeldahl method (4611.02); the nitrogen-to-protein conversion factor was 5.7. Total carbohydrate (\%) content was calculated as the difference: $100-$ (moisture + ash + proteins + lipids + crude fibers), a method reported also by Kasaye and Jha [13]. Water absorption capacity (WAC) was determined by the method described by Sosulski et al. [14] and modified by Chandra et al. [15]. One gram of sample was mixed with $10 \mathrm{~mL}$ distilled water, allowed to stand at ambient temperature $\left(30 \pm 2^{\circ} \mathrm{C}\right)$ for $30 \mathrm{~min}$, and then centrifuged for $30 \mathrm{~min}$ at $3000 \mathrm{rpm}$ or $2000 \times \mathrm{g}$. The volume of water on the sediment water was measured. Water absorption capacities were calculated as $\mathrm{ml}$ of water absorbed per gram of flour, and expressed in \%. Two hour after baking, the loaves were weighed and bread volume was determined according to AACC Approved Method 10-05.01 procedure [12]. The weight of the bread was taken using a digital balance. The bread volume was determined by the seeds displacement method. The volume of seeds displaced by the loaf was considered as the loaf bread volume. Specific volume (SV) of bread was expressed as the volume/weight ratio $\left(\mathrm{cm}^{3} / \mathrm{g}\right)$ multiplied by 100 of finished bread.

2.3. Baking Test. Experimental breads were obtained from wheat flour type 1250 blends containing $0 \%$ (100\% wheat flour type 1250 ) and $2 \%, 5 \%$, and $8 \%$ of FF (as wheat flour replacement). The bread prepared, from wheat flour without
FF substitution, was served as control. The bread dough was obtained according to AACC 10-10.03 in a laboratory spiral mixer (type Hobart) by kneading $1000 \mathrm{~g}$ flour, $18 \mathrm{~g}$ iodized salt, and $25 \mathrm{~g}$ fresh yeast (Pakmaya Yeast Rompak, Romania) with water $650 \mathrm{ml}$ for control bread (B_WO) and $670 \mathrm{ml}$, $685 \mathrm{ml}, 700 \mathrm{ml}$, respectively, for bread supplemented with fenugreek flour (B_WF2\%, B_WF5\%, and B_WF8\%,), in order to achieve the specific consistence. For this purpose, the correct water amount was obtained by assessing the blends' WAC. First step was dough kneading for about 8-10 minutes, after that the dough was maintained for 60-90 minutes at a temperature of $28-32^{\circ} \mathrm{C}$ for bulk fermentation. Next step is dividing the dough into two equal-weight parts and shaping them in an oval shape, after which the pieces are placed in trays and introduced into the fermentation room for 3040 minutes at a temperature of $35-40^{\circ} \mathrm{C}$ and relative humidity of $75-85 \%$. After the fermentation, the products are baked at a temperature of $220^{\circ} \mathrm{C}$ for about $30-40$ minutes.

\subsection{Total Phenols and Antioxidant Activity Determination.} Total polyphenol content and antioxidant activity extracts from the samples were prepared as described by Bunea et al. [16] with some slight modifications by Chiş et al. [17]. Shortly, one gram of sample was extracted three times with $100 \mathrm{~mL}$ acidified methanol $(85: 15 \mathrm{v} / \mathrm{v}, \mathrm{MeOH}: \mathrm{HCl})$ by maceration under continuous stirring (Velp magnetic stirrer, EU) for $24 \mathrm{~h}$. The filtrates were combined in a total extract, which was dried by using a vacuum rotary evaporator at $40^{\circ} \mathrm{C}$. The dry residues were redissolved in $10 \mathrm{~mL}$ methanol (99.9\% purity) and filtered through a $0.45 \mu \mathrm{m}$ nylon filter (Millipore) [17].

The content of total phenolics in extracts was determined by the Folin-Ciocalteu method described by Singleton and Joseph [18] modified by Dordević et al. [19]. Shortly, $100 \mu \mathrm{l}$ of each extract was shaken for 1 min with $500 \mu \mathrm{l}$ of FolinCiocalteu reagent and $6 \mathrm{~mL}$ of distilled water. After the mixture was shaken, $2 \mathrm{~mL}$ of $15 \% \mathrm{Na}_{2} \mathrm{CO}_{3}$ was added and the mixture was shaken once again for $0.5 \mathrm{~min}$. Finally, the solution was brought up to $10 \mathrm{~mL}$ by adding distilled water. Samples were kept in the dark for $2 \mathrm{~h}$, and then, absorbance was read at $720 \mathrm{~nm}$ on the UV/visible spectrophotometer Schimadzu 1700 (Japan). The total phenol content was assessed by plotting the gallic acid calibration curve (from 1 to $1500 \mu \mathrm{g} / \mathrm{mL}$ ) and expressed as milligrams of gallic acid equivalents (GAE) per gram of dried extract. The equation for the gallic acid calibration curve was $y=1.02295 x+$ $0.08740, R^{2}=0.99614$.

The antioxidant activity was determined by using the radical DPPH (2,2-diphenyl-1- picrylhydrazyl) scavenging capacity assay as described by Nenadis and Tsimidou [20] and modified by Dordević et al. [19]. The phenolic extracts $(0.1 \mathrm{~mL})$ were mixed with DPPH solution $(3.9 \mathrm{~mL})$, kept in the dark at ambient temperature, and the absorbance of the mixtures was recorded at $515 \mathrm{~nm}$ after exactly 30 minutes against methanol as blank. Negative control was prepared using $0.1 \mathrm{~mL}$ methanol and $3.9 \mathrm{~mL}$ of DPPH. The radicalscavenging activity was calculated according to the following equation: 


$$
\operatorname{RSA}[\%]=\frac{\mathrm{Abs}_{\mathrm{DPPH}} \cdot \mathrm{Abs}_{\text {sample }}}{\mathrm{Abs}_{\mathrm{DPPH}}} \cdot 100,
$$

where $\mathrm{Abs}_{\mathrm{DPPH}}=$ absorbance of $\mathrm{DPPH}$ solution and $\mathrm{Abs}_{\text {sample }}=$ absorbance of the sample.

2.5. Texture Profile Analysis for Bread Samples. CT 3 Texture Analyzer (Brookfield Engineering Labs), equipped with $10 \mathrm{~kg}$ load cell and the TA11/1000 cylindrical probe $(25.4 \mathrm{~mm}$ diameter AOAC Standard Clear Acrylic $21 \mathrm{~g}$, $35 \mathrm{~mm}$ length), was used in a texture profile analysis test (40\% target deformation, $1 \mathrm{~mm} \mathrm{~s}^{-1}$ test and posttest speed, $5 \mathrm{~g}$ trigger load, and $5 \mathrm{~s}$ recovery time). The specific texture parameters were computed by Texture Pro CT V1.6 software [21].

2.6. Sensory Evaluation. The sensory characteristics of bread were evaluated by 25 trained sensory panels. The panelists were asked to evaluate colour, aroma, taste, flavor, texture, and overall acceptability of the samples on a 9-point hedonic scale, ranging from 9 as like extremely to 1 as dislike extremely.

2.7. Microbiological Analysis. Total plate, yeast and molds, Coliforms, and E. coli counts were enumerated in bread samples supplemented with fenugreek flour according to the (EC) No 1441/2007 [22].

2.8. Statistical Analysis. The results of three independent $(n=3)$ assays performed with replicates each were expressed as means \pm standard deviations. Data were analyzed by oneway analysis of variance (ANOVA) using Minitab Statistical Software v.16, for each parameter, Tukey's comparison tests were performed at a $95 \%$ confidence level; several correlations were computed by IBM SPPS Statistics 19, while principal component analysis was performed by The Unscrambler X v.10.5.1 software.

\section{Results and Discussion}

3.1. Chemical Composition of Flour. Chemical parameters for blends of fenugreek flour and wheat flour type 1250 are shown in Table 1.

High nutrient potential of fenugreek flour in large part is due to the high content of protein and fiber. As mentioned on several sources, the total protein content is between 20 and $30.1 \%$ [23], while the total fiber content of fenugreek flour is between 40 and $45 \%$, in most part insoluble fiber is $20.1-25.3 \%[6,8]$. In the current work, it was noticed that protein, ash, fat, and fiber percent of the flour blends increased as the supplementation level of fenugreek flour increased in the blend with the highest values at $8 \% \mathrm{FF}$ addition. These results are in agreement with those obtained by Kasaye and Jha [13]. This increment, in the crude fiber, ash, and lipid contents, is beneficial for health since FF can provide important amounts of potassium, magnesium, calcium, iron, and zinc [5] as well as unsaturated fatty acids. The total phenolic content (TCP) in different substitutions of FF ranged from $136 \pm 4.24 \mathrm{mg}$ GAE/100 g (S0) to $379 \pm 5.66 \mathrm{mg}$ GAE/100 g (S3). The antioxidant activity (DPPH) in wheat-fenugreek flour ranged from $33 \pm 5.66 \%$ (S0) to $54 \pm 4.24 \%$ (S3); results are consistent with Afzal et al. [6]. The increase in the WAC for composite flours could be associated with the hydrophilic character of the protein of fenugreek flour [24].

3.2. Physicochemical Properties of Loaf Bread. Physicochemical characteristics of bread supplemented with fenugreek flour are presented in Table 2.

The high fiber and protein content of the FF, compared to the wheat flour, contributed to a higher WAC in the finished product and consequently increased the product weight. Collar et al. [25] concluded that the physical properties of fiber including water holding, oil holding and swelling capacity, and viscosity or gel formation significantly affect product processing and quality. According to the results shown in Table 2, significant reduction in specific loaf volume was observed at all the levels of FF supplementation. Maximum reduction in loaf specific volume was observed in case of $8 \% \mathrm{FF}$ supplementation level. This may be due to the dilution effect on gluten content with the addition of gluten-free flour to wheat flour that has been reported to be associated with specific loaf volume-decreasing effect of composite flours [26]. Also, the additions of fibers to bakery products lead to the decrease of their volume as confirmed by the negative regression coefficient obtained as $r=-0.987$.

Moisture content increased on fortification with FF, which can be attributed to the high water binding capacity of seed flour. The protein content in wheat bread increased significantly $(p<0.05)$ with the amount of substitution of FF. The bread fortified with $8 \% \mathrm{FF}$ had significantly higher protein content, and a negative linear relationship $(r=0.991)$ between protein content and specific loaf volume was noticed. Similarly, Sharma and Chauhan [26] reported significantly higher protein content in breads prepared from blends of wheat-fenugreek flours. Regarding the bread ash content and the crude fiber, in relation with the FF addition, there is a direct proportional increase between these parameters and the percentage of $\mathrm{FF}$ incorporated. The coefficients of correlation of $r=0.976$ indicate a perfect positive linear relationship between these two parameters. Fat content of wheat bread significantly increased on the substitution of fenugreek flour. This is in agreement with Sharma and Chauhan [26] and Chaubey et al. [8]. Total carbohydrate decreased as the FF increased, due to the high content in protein, fat, crude fiber, lipid, and moisture of FF, resulting in a final product enriched in all these bioactive compounds. The highest total phenolic content (TPC) was found in B_WF8\% followed by B_WF5\% and B_WF2\%. The antioxidant activity (DPPH) value for bread prepared from wheat flour was found to be lower than fenugreek-supplemented bread, registering a linear increase. The coefficients of correlation of $r=0.998$ and $r=0.999$ indicate a positive linear relationship between 
TABLe 1: Chemical composition (\%) of wheat and wheat-fenugreek flour blends.

\begin{tabular}{|c|c|c|c|c|}
\hline Parameters & W0 & WF2\% & WF5\% & WF8\% \\
\hline Moisture (\%) & $13.80 \pm 0.01^{\mathrm{a}}$ & $13.70 \pm 0.03^{\mathrm{a}}$ & $13.07 \pm 0.06^{\mathrm{b}}$ & $12.79 \pm 0.04^{\mathrm{c}}$ \\
\hline Protein $(\%)$ & $10.90 \pm 0.07^{\mathrm{d}}$ & $11.79 \pm 0.03^{\mathrm{c}}$ & $13.02 \pm 0.03^{\mathrm{b}}$ & $14.07 \pm 0.07^{\mathrm{a}}$ \\
\hline Ash (\%) & $1.24 \pm 0.01^{\mathrm{c}}$ & $1.29 \pm 0.04^{\mathrm{bc}}$ & $1.38 \pm 0.03^{\mathrm{ab}}$ & $1.44 \pm 0.04^{\mathrm{a}}$ \\
\hline Fat $(\%)$ & $1.09 \pm 0.02^{\mathrm{d}}$ & $1.31 \pm 0.02^{\mathrm{c}}$ & $1.47 \pm 0.02^{\mathrm{b}}$ & $1.69 \pm 0.02^{\mathrm{a}}$ \\
\hline Crude fiber (\%) & $0.75 \pm 0.21^{\mathrm{c}}$ & $1.75 \pm 0.04^{\mathrm{b}}$ & $2.07 \pm 0.03^{\mathrm{ab}}$ & $2.43 \pm 0.06^{\mathrm{a}}$ \\
\hline Water absorption capacity (\%) & $65 \pm 4.24^{\mathrm{a}}$ & $67 \pm 2.82^{\mathrm{a}}$ & $68.5 \pm 4.95^{\mathrm{a}}$ & $70 \pm 4.24^{\mathrm{a}}$ \\
\hline TPC (mgGAE/100 g) & $136 \pm 4.24^{\mathrm{d}}$ & $207 \pm 7.07^{\mathrm{c}}$ & $317 \pm 4.24^{\mathrm{b}}$ & $379 \pm 5.66^{\mathrm{a}}$ \\
\hline DPPH $(\%)$ & $33 \pm 5.66^{\mathrm{b}}$ & $47 \pm 2.83^{\mathrm{ab}}$ & $51 \pm 4.24^{\mathrm{a}}$ & $54 \pm 4.24^{\mathrm{a}}$ \\
\hline
\end{tabular}

Values are expressed as mean \pm standard deviation. W0 $=$ wheat flour; WF $2 \%=2 \%$ fenugreek flour-supplemented wheat flour; WF $5 \%=5 \%$ fenugreek floursupplemented wheat flour; WF8 $\%=8 \%$ fenugreek flour-supplemented wheat flour. TPC: total phenolic content; GAE: gallic acid equivalents (FolinCiocalteu method); CE: catechin equivalents; DPPH: 2,2-diphenyl-1-picrylhydrazyl; FRAP: ferric-reducing antioxidant powder. Identical superscript letters within rows indicate no significant difference $(p>0.05)$.

TABLE 2: Chemical characteristics of bread supplemented with fenugreek flour.

\begin{tabular}{|c|c|c|c|c|}
\hline \multirow{2}{*}{ Characteristics } & \multicolumn{4}{|c|}{ Bread samples } \\
\hline & B_W0 & B_WF2\% & B_WF5\% & B_WF8\% \\
\hline Specific loaf volume $\left(\mathrm{cm}^{3} / 100 \mathrm{~g}\right)$ & $263.2 \pm 0.62^{\mathrm{a}}$ & $251.8 \pm 0.55^{\mathrm{b}}$ & $242.08 \pm 0.28^{\mathrm{c}}$ & $231.55 \pm 0.4^{\mathrm{d}}$ \\
\hline Moisture (\%) & $43.27 \pm 0.30^{\mathrm{a}}$ & $43.57 \pm 0.48^{\mathrm{a}}$ & $43.92 \pm 0.47^{\mathrm{a}}$ & $44.17 \pm 0.37^{\mathrm{a}}$ \\
\hline Protein $(\%)$ & $9.88 \pm 0.08^{c}$ & $10.66 \pm 0.32^{c}$ & $11.96 \pm 0.5^{\mathrm{b}}$ & $13.18 \pm 0.08^{\mathrm{a}}$ \\
\hline Ash $(\%)$ & $1.36 \pm 0.03^{\mathrm{c}}$ & $1.41 \pm 0.06^{\mathrm{bc}}$ & $1.49 \pm 0.03^{\mathrm{ab}}$ & $1.52 \pm 0.04^{\mathrm{a}}$ \\
\hline Fat $(\%)$ & $1.52 \pm 0.03^{\mathrm{d}}$ & $1.75 \pm 0.08^{c}$ & $1.91 \pm 0.05^{\mathrm{b}}$ & $2.12 \pm 0.06^{\mathrm{a}}$ \\
\hline Crude fiber $(\%)$ & $1.72 \pm 0.04^{\mathrm{d}}$ & $2.08 \pm 0.07^{\mathrm{c}}$ & $2.78 \pm 0.12^{\mathrm{b}}$ & $3.47 \pm 0.14^{\mathrm{a}}$ \\
\hline Total carbohydrate (\%) & $41.95 \pm 1.06^{\mathrm{a}}$ & $40.23 \pm 0.19^{\mathrm{b}}$ & $37.64 \pm 0.55^{\mathrm{c}}$ & $35.14 \pm 0.27^{\mathrm{d}}$ \\
\hline TPC (mgGAE/100g) & $105 \pm 4.24^{\mathrm{d}}$ & $157 \pm 5.66^{\mathrm{c}}$ & $243 \pm 2.83^{\mathrm{b}}$ & $349 \pm 4.24^{\mathrm{a}}$ \\
\hline DPPH $(\%)$ & $29 \pm 1.7^{\mathrm{c}}$ & $35 \pm 1.41^{\mathrm{c}}$ & $44 \pm 1.4^{\mathrm{b}}$ & $55 \pm 1.41^{\mathrm{a}}$ \\
\hline
\end{tabular}

${ }^{*}$ B_W $0=100 \%$ wheat flour $+0 \%$ fenugreek flour; $B_{-}$WF $2 \%=98 \%$ wheat flour $+2 \%$ fenugreek flour; B_WF5 $\%=95 \%$ wheat flour $+5 \%$ fenugreek flour; B_WF $\%=92 \%$ wheat flour $+8 \%$ fenugreek flour. All analyses were made in triplicate, and mean values were recorded ( \pm standard deviations). Identical superscript letters within rows indicate no significant difference $(p>0.05)$.

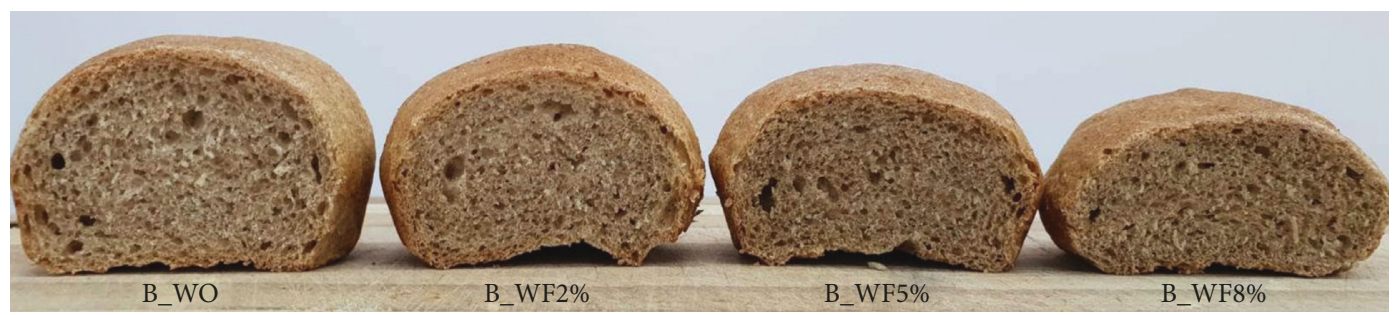

Figure 1: Sections of the obtained wheat-fenugreek bread samples as compared to a control dark wheat bread. B_WO=100\% wheat flour $+0 \%$ fenugreek flour; B_WF $\%=98 \%$ wheat flour $+2 \%$ fenugreek flour; B_WF5\% $=95 \%$ wheat flour $+5 \%$ fenugreek flour; B_WF $8 \%=92 \%$ wheat flour $+8 \%$ fenugreek flour.

the TPC and DPPH and protein content and the crude fiber. Similar results have been obtained by Afzal et al. [6]. Good results in supplementation of wheat-based products with FF were reported by Hooda and Jood [27], which concluded that the supplementation can be made up to $20 \%$ in products like bread, biscuits, noodles, and macaroni, without affecting the product quality. Same authors, Hooda and Jood [23], concluded that FF can be used in bread up to a level of $15 \%$, the best results being obtained on germinated fenugreek flour-supplemented bread, which showed satisfactory organoleptic and baking characteristics and contained important amounts of total protein, lysine, dietary fibers, and minerals.
3.3. Texture Profile Analyses. Figure 1 presents the sections of the obtained wheat-fenugreek bread samples, in comparison with wheat control bread.

A good baking behavior was observed for all samples. Texture profile analysis was considered the most relevant test in order to objectively compare the bread samples, the main textural parameters being presented in Table 3. Breads made with the three levels $(2 \%, 5 \%$, and $8 \%)$ of $\mathrm{FF}$ had similar scores for crumb hardness compared with the control $(p>0.05)$. This may be due to the emulation properties of fenugreek protein content and its role in improving bread keeping quality; similar results were reported previously [24]. 
TABLE 3: Texture profile analyses for bread samples supplemented with fenugreek flour.

\begin{tabular}{|c|c|c|c|c|}
\hline \multirow{2}{*}{ Parameters } & \multicolumn{4}{|c|}{ Bread samples } \\
\hline & B_W0 & B_WF2\% & B_WF5\% & B_WF8\% \\
\hline Sample length (mm) & $26.95 \pm 0.96^{\mathrm{a}}$ & $26.28 \pm 1.04^{\mathrm{ab}}$ & $24.00 \pm 0.86^{\mathrm{b}}$ & $25.66 \pm 0.96^{\mathrm{ab}}$ \\
\hline Hardness cycle $1(\mathrm{~g})$ & $544 \pm 84^{\mathrm{a}}$ & $561 \pm 164^{\mathrm{a}}$ & $602 \pm 128^{\mathrm{a}}$ & $580 \pm 92^{\mathrm{a}}$ \\
\hline Total work cycle $1(\mathrm{~mJ})$ & $41.1 \pm 5.4^{\mathrm{a}}$ & $38.4 \pm 17.4^{\mathrm{a}}$ & $33.6 \pm 6.2^{\mathrm{a}}$ & $33.4 \pm 7.1^{\mathrm{a}}$ \\
\hline Hardness cycle $2(\mathrm{~g})$ & $509 \pm 81^{\mathrm{a}}$ & $530 \pm 143^{\mathrm{a}}$ & $578 \pm 123^{\mathrm{a}}$ & $555 \pm 86^{\mathrm{a}}$ \\
\hline Total work cycle $2(\mathrm{~mJ})$ & $30.9 \pm 3.9^{\mathrm{a}}$ & $30.2 \pm 11.9^{\mathrm{a}}$ & $27.8 \pm 5.0^{\mathrm{a}}$ & $27.3 \pm 5.5^{\mathrm{a}}$ \\
\hline Cohesiveness (n.a.) & $0.70 \pm 0.02^{\mathrm{b}}$ & $0.76 \pm 0.05^{\mathrm{ab}}$ & $0.79 \pm 0.01^{\mathrm{a}}$ & $0.77 \pm 0.01^{\mathrm{ab}}$ \\
\hline Springiness index (n.a.) & $0.89 \pm 0.02^{\mathrm{a}}$ & $0.90 \pm 0.03^{\mathrm{a}}$ & $0.91 \pm 0.02^{\mathrm{a}}$ & $0.9 \pm 0.01^{\mathrm{a}}$ \\
\hline Gumminess (g) & $382 \pm 58^{\mathrm{a}}$ & $418 \pm 94^{\mathrm{a}}$ & $474 \pm 98^{\mathrm{a}}$ & $448 \pm 68^{\mathrm{a}}$ \\
\hline Chewiness index $(\mathrm{g})$ & $342 \pm 58^{\mathrm{a}}$ & $379 \pm 95^{\mathrm{a}}$ & $433 \pm 89^{a}$ & $403 \pm 58^{\mathrm{a}}$ \\
\hline
\end{tabular}

${ }^{*}$ B_W $0=100 \%$ wheat flour $+0 \%$ fenugreek flour; B_WF $2 \%=98 \%$ wheat flour $+2 \%$ fenugreek flour; B_WF5\% $=95 \%$ wheat flour $+5 \%$ fenugreek flour; B_WF8\% $=92 \%$ wheat flour $+8 \%$ fenugreek flour. All analyses were made in triplicate, and mean values were recorded ( \pm standard deviations). Identical superscript letters within rows indicate no significant difference $(p>0.05)$.

TABLe 4: Sensory evaluation of different bread samples.

\begin{tabular}{lccccc}
\hline Bread samples & Colour & Aroma & Taste & Texture & Overall acceptability \\
\hline B_W0 & $8.40 \pm 0.50^{\mathrm{a}}$ & $7.68 \pm 1.145^{\mathrm{a}}$ & $7.72 \pm 1.14^{\mathrm{a}}$ & $8.52 \pm 0.65^{\mathrm{a}}$ & $8.16 \pm 0.55^{\mathrm{a}}$ \\
B_WF2\% & $8.36 \pm 0.49^{\mathrm{a}}$ & $7.72 \pm 1.1^{\mathrm{a}}$ & $7.68 \pm 1.15^{\mathrm{a}}$ & $8.48 \pm 0.65^{\mathrm{a}}$ & $8.00 \pm 0.71^{\mathrm{a}}$ \\
B_WF5\% & $8.32 \pm 0.56^{\mathrm{a}}$ & $7.80 \pm 1.00^{\mathrm{a}}$ & $7.64 \pm 1.11^{\mathrm{a}}$ & $8.40 \pm 0.71^{\mathrm{a}}$ & $7.96 \pm 0.73^{\mathrm{a}}$ \\
B_WF8\% & $8.28 \pm 0.61^{\mathrm{a}}$ & $7.28 \pm 0.98^{\mathrm{a}}$ & $7.00 \pm 1.16^{\mathrm{a}}$ & $8.32 \pm 0.69^{\mathrm{a}}$ & $7.40 \pm 0.87^{\mathrm{b}}$ \\
\hline
\end{tabular}

${ }^{*}$ B_W $0=100 \%$ wheat flour $+0 \%$ fenugreek flour; B_WF $2 \%=98 \%$ wheat flour $+2 \%$ fenugreek flour; $B \_W F 5 \%=95 \%$ wheat flour $+5 \%$ fenugreek flour; B_WF8\% $=92 \%$ wheat flour $+8 \%$ fenugreek flour. All analyses were made in triplicate, and mean values were recorded ( \pm standard deviations). Identical superscript letters within columns indicate no significant difference $(p>0.05)$.

The apparent increase in the hardness (Cycle 1) of fenugreek bread samples (mean values of 544 to $602 \mathrm{~g}$ ) could be related to the reduction of gluten amount, as a result of increase in FF level; however, the statistical analysis revealed no significant differences $(p>0.05)$, emphasizing the future possible uses of fenugreek in bread-making process. Gluten is the main protein that has a significant role in bread texture and volume. Therefore, when the amount of gluten in the dough is reduced, it may result in a harder bread texture [28]. Textural properties could be improved by sourdough utilization [29]. Likewise, the gumminess and chewiness, which is proportional to the hardness, showed similar trends. Gumminess is proportional to hardness and cohesiveness while chewiness is proportional to hardness, cohesiveness, and springiness. FF had high water-holding capacity due to the hydrophilic character of the molecules, thereby preserving the appropriate moisture and maintaining the texture profiles up to a 5\% FF addition [24], as can be seen by cohesiveness values.

3.4. Sensory Analysis. When fenugreek was added in wheat flour, it modified the sensory attributes like taste and mouth feel of the product (Table 4). There was a decreasing trend for aroma and taste, probably due to fenugreek flavor [27].

The mean scores of sensory attributes ranged between 7.40 and 8.16 for the tested samples. Bread prepared with $100 \%$ of wheat flour scored maximum than the rest of the samples. There was an apparent decreasing trend for aroma and taste (from 7.68 to 7.28 for aroma and from 7.72 to 7 for taste), probably due to FF; however, the statistical analysis revealed no significant difference in between these values, as can be seen in Table 4 . The specific aroma of fenugreek seeds came from polysaccharides (galactomannan), volatile oils, and alkaloids, such as choline and trigonelline [28]. The mean scores decreased as the proportion of FF increased in the blends. The highest value was recorded for bread made with $2 \% \mathrm{FF}$ while the lowest value was for $8 \% \mathrm{FF}$ with wheat flour, which showed a significantly different overall acceptability score ( $p>0.05$; Table 4$)$; the results are confirmed by principal component analysis which revealed a different pattern only for B_WF8\% (Figure 2(a)). There were no significant difference $(p>0.05)$ among control sample and bread containing $2 \%$ and, respectively, $5 \% \mathrm{FF}$, with respect to sensory characteristics. Overall, a similar clustering was noticed when performing the PCA analysis (Figure 2(b)) while including all physicochemical, textural, and sensory parameters as mentioned on Tables 2-4. These results strengthen the hypotheses that bread supplementation up to $5 \%$ fenugreek flour is optimal in terms of sensory and texture parameters while improving the antioxidant content of the samples.

3.5. Microbiological Analysis. The antimicrobial activity of the fenugreek, as was reported by Al-Habori and Raman [30] and Mercan et al. [31], could be noticed by results of microbial analysis (Table 5), since fenugreek-based breads had lower microbial counts than control samples. Results are according to the EU Regulation nr. 1441/2007 [22]. In a 


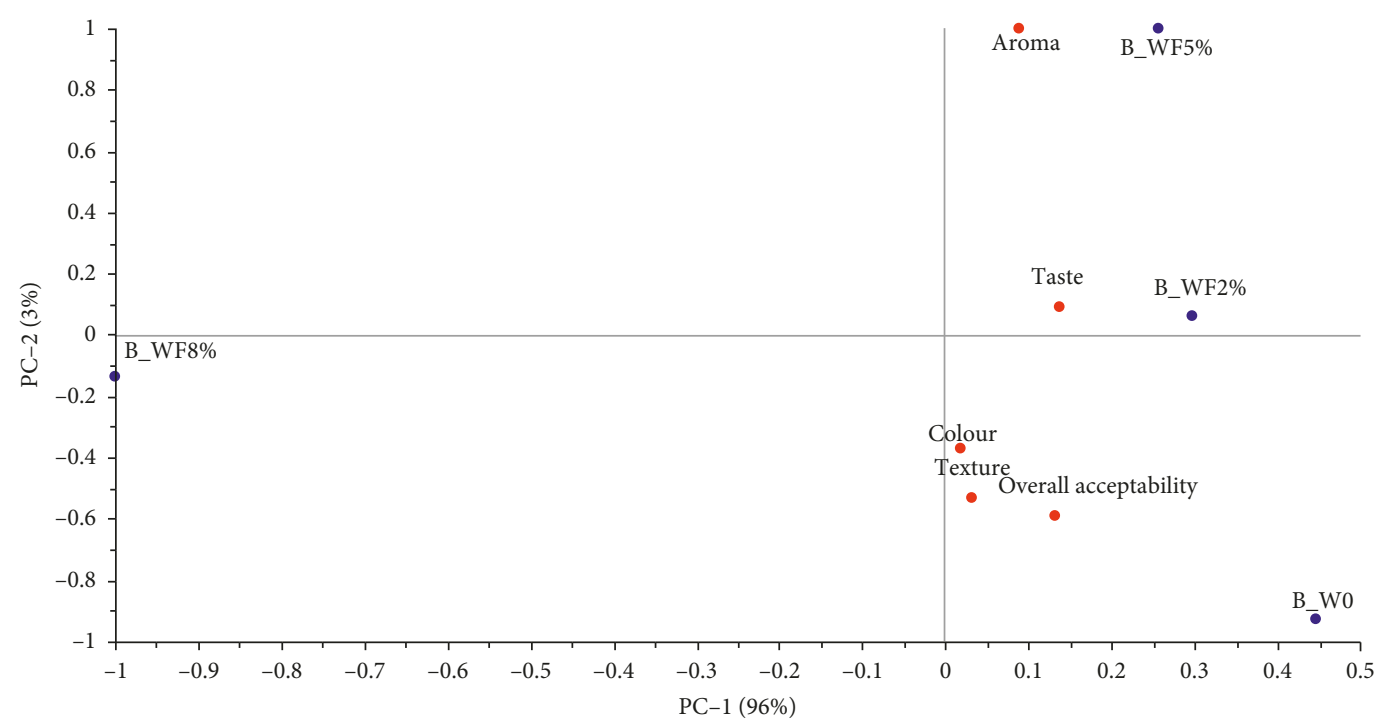

(a)

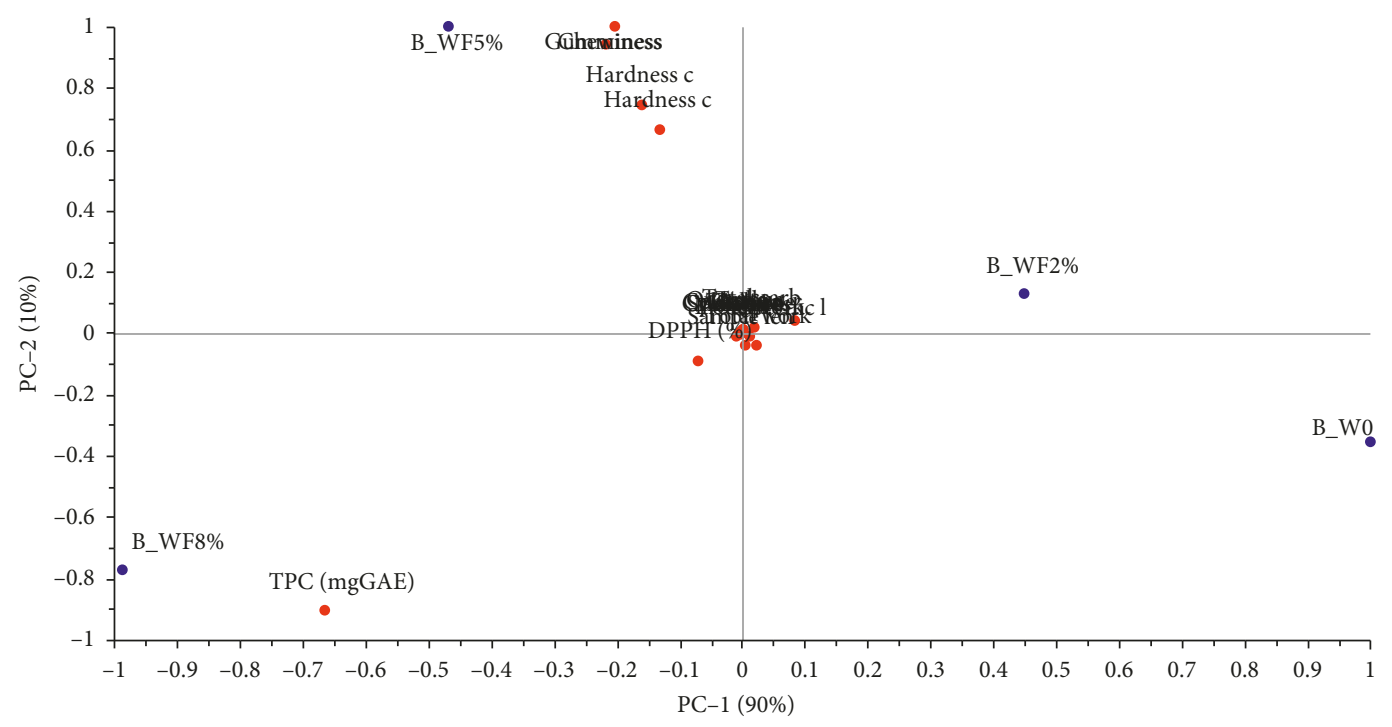

(b)

FIgURE 2: Principal component analysis biplots for wheat-fenugreek bread samples as compared to a control dark wheat bread: (a) sensory characteristics; (b) all physicochemical, textural, and sensory parameters (Tables 2-4). Figure 2(b) is shown in the Supplementary Materials section without overlapping as Figures S2b and S2c (center zoom). B_WO $=100 \%$ wheat flour $+0 \%$ fenugreek flour; B_WF2\% $=98 \%$ wheat flour $+2 \%$ fenugreek flour; B_WF5\% $=95 \%$ wheat flour $+5 \%$ fenugreek flour; B_WF8\% $=92 \%$ wheat flour $+8 \%$ fenugreek flour. Figure 2(b) is showed at Supplementary Material section without overlapping as Figures S2b and S2c (center zoom).

TABLE 5: Microbiological analysis of bread supplemented with fenugreek flour.

\begin{tabular}{lcccc}
\hline Microbial counts & \multicolumn{2}{c}{ Microbial load of samples (cfu/g) } \\
& B_W0 & B_WF2\% & B_WF5\% & $1.3 \times 10^{2}$ \\
TPC & $1.2 \times 10^{3}$ & $1 \times 10^{3}$ & ND & $0.9 \times 10^{2}$ \\
Yeast and mold count & 10 & ND & ND & ND \\
Coliform count & ND & ND & ND \\
E. coli count & ND & ND & ND & ND \\
\hline
\end{tabular}

TPC: total plate count; B_W0: $100 \%$ wheat flour + 0\% fenugreek flour; B_WF2\%: $98 \%$ wheat flour $+2 \%$ fenugreek flour; B_WF5\%: 95\% wheat flour + $5 \%$ fenugreek flour; B_WF8\%: $92 \%$ wheat flour $+8 \%$ fenugreek flour; ND: not detected. 
study, honey samples with highest antibacterial activity against Staphylococcus aureus, Pseudomonas aeruginosa, and Escherichia coli show maximum pollens from fenugreek than other plants [31].

\section{Conclusions}

Fenugreek flour could be incorporated up to $8 \%$ level in the formulation of bread without affecting its overall quality. The sensory evaluation indicated that the sample fortified with $2 \%$ and $5 \% \mathrm{FF}$ had the highest acceptability score. However, taking into account the health benefits of fenugreek bioactive compounds and the results of quality characteristics, one can conclude that bread supplementation up to $5 \%$ fenugreek flour is optimal.

\section{Data Availability}

The data used to support the findings of this study are included within the article and also in the supplementary information file.

\section{Conflicts of Interest}

The authors declare that there are no conflicts of interest regarding the publication of this paper.

\section{Acknowledgments}

The authors acknowledge the technical support of Eng. Maria Anca Deoancă (Paşca).

\section{Supplementary Materials}

Table S1: Pearson correlations between physicochemical, textural, and sensory parameters. This section also contains Figures S2b and S2c (center zoom of Figure S2b). (Supplementary Materials)

\section{References}

[1] E. Basch, C. Ulbricht, G. Kuo, P. Szapary, and M. Smith, "Therapeutic applications of fenugreek," Alternative Medicine Review, vol. 8, no. 1, pp. 20-27, 2003.

[2] A. Djeridane, M. Yousfi, B. Nadjemi, D. Boutassouna, P. Stocker, and N. Vidal, "Antioxidant activity of some algerian medicinal plants extracts containing phenolic compounds," Food Chemistry, vol. 97, no. 4, pp. 654-660, 2006.

[3] N. Moradi Kor and K. Moradi, "Physiological and pharmaceutical effects of fenugreek (Trigonella foenum-graecum L.) as a multipurpose and valuable medicinal plant," Global Journal of Medicinal Plants Research, vol. 1, pp. 199-206, 2013.

[4] J. N. Losso, D. L. Holliday, J. W. Finley et al., "Fenugreek bread: a treatment for diabetes mellitus," Journal of Medicinal Food, vol. 12, no. 5, pp. 1046-1049, 2009.

[5] A. Ahmad, S. S. Alghamdi, K. Mahmood, and M. Afzal, "Fenugreek a multipurpose crop: potentialities and improvements," Saudi Journal of Biological Sciences, vol. 23, no. 2, pp. 300-310, 2016.

[6] B. Afzal, I. Pasha, T. Zahoor, and H. Nawaz, "Nutritional potential of fenugreek supplemented bread with special reference to antioxidant profiling," Pakistan Journal of Agricultural Sciences, vol. 53, no. 1, pp. 217-223, 2016.

[7] M. Joglekar, M. Mandal, M. P. Somaiah, and S. Murthy, "Comparative analysis of antioxidant and antibacterial properties of Aegle marmelos, Coriandrum sativum and Trigonella foenum graecum," Acta Biologica Indica, vol. 1, no. 1, pp. 105-108, 2012.

[8] P. S. Chaubey, G. Somani, D. Kanchan, S. Sathaye, S. Varakumar, and R. S. Singhal, "Evaluation of debittered and germinated fenugreek (Trigonella foenum graecum L.) seed flour on the chemical characteristics, biological activities, and sensory profile of fortified bread," Journal of Food Processing and Preservation, vol. 42, no. 1, article e13395, 2018.

[9] K. Srinivasan, "Fenugreek (Trigonella foenum-graecum): a review of health beneficial physiological effects," Food Reviews International, vol. 22, no. 2, pp. 203-224, 2006.

[10] A. M. S. Hussein, A. S. Abd, A. M. El-Azeem, and A. A. Hegazy, "Physiochemical, sensory and nutritional properties of cornfenugreek flour composite biscuits," Australian Journal of Basic Applied Sciences, vol. 5, pp. 84-95, 2011.

[11] S. A. Wani and P. Kumar, "Fenugreek: a review on its nutraceutical properties and utilization in various food products," Journal of the Saudi Society of Agricultural Sciences, vol. 17, no. 2, pp. 97-106, 2018.

[12] AACC, Approved Methods of the American Association of Cereal Chemists, American Association of Cereal Chemists, St. Paul, MN, USA, 11th edition, 2000.

[13] A. T. Kasaye and Y. K. Jha, "Evaluation of composite blends of fermented fenugreek and wheat flour to assess its suitability for bread and biscuit," International Journal of Nutrition and Food Sciences, vol. 4, no. 1, pp. 29-35, 2015.

[14] F. Sosulski, M. D. Garratt, and A. E. Slimkard, "Functional properties of ten legume flours," Canadian Institute of Food Science and Technology Journal, vol. 9, no. 2, pp. 66-69, 1976.

[15] S. Chandra, S. Singh, and D. Kumari, "Evaluation of functional properties of composite flours and sensorial attributes of composite flour biscuits," Journal of Food Science and Technology, vol. 52, no. 6, pp. 3681-3688, 2014.

[16] A. Bunea, O. D. Rugina, A. M. Pintea, Z. Sconţa, C. I. Bunea, and C. Socaciu, "Comparative polyphenolic content and antioxidant activities of some wild and cultivated blueberries from Romania," Notulae Botanicae Horti Agrobotanici ClujNapoca, vol. 39, no. 2, pp. 70-76, 2011.

[17] M. S. Chiş, A. Păucean, L. Stan et al., "Lactobacillus plantarum ATCC 8014 in quinoa sourdough adaptability and antioxidant potential," Romanian Biotechnological Letters, vol. 23, no. 3, pp. 13581-13591, 2018.

[18] V. L. Singleton and A. R. Joseph, "Colorimetry of total phenolics with phosphomolybdic-phosphotungstic acid reagents," American Journal of Enology and Viticulture, vol. 16, no. 3, pp. 144-148, 1965.

[19] T. M. Dordević, S. S. Šiler-Marinković, and S. I. DimitrijevićBranković, "Effect of fermentation on antioxidant properties of some cereals and pseudocereals," Food Chemistry, vol. 119, no. 3, pp. 957-963, 2010.

[20] N. Nenadis and M. Tsimidou, "Observations on the estimation of scavenging activity of phenolic compounds using rapid 1,1-diphenyl-2-picrylhydrazyl (DPPH) tests," Journal of the American Oil Chemists' Society, vol. 79, no. 12, pp. 1191-1195, 2002.

[21] A. Păucean, O. P. Moldovan, V. Mureşan et al., "Folic acid, minerals, aminoacids, fatty acids and volatile compounds of green and red lentils: folic acid content optimization in wheat- 
lentils composite flours," Chemistry Central Journal, vol. 12, no. 1, p. 88, 2018.

[22] Commission Regulation (EC) No 1441/2007 of 5 December 2007 amending Regulation.

[23] S. Hooda and S. Jood, "Effect of fenugreek flour blending on physical, organoleptic and chemical characteristics of wheat bread," Nutrition \& Food Science, vol. 35, no. 4, pp. 229-242, 2005.

[24] N. A. E. Nasri and A. H. Tinay, "Functional properties of fenugreek (Trigonella foenum graecum) protein concentrate," Food Chemistry, vol. 103, no. 2, pp. 582-589, 2007.

[25] C. Collar, E. Santos, and C. M. Rosell, "Assessment of the rheological profile of fibre-enriched bread doughs by response surface methodology," Journal of Food Engineering, vol. 78, no. 3, pp. 820-826, 2007.

[26] H. R. Sharma and G. S. Chauhan, "Physical, sensory and chemical characteristics of wheat breads supplemented with fenugreek," Journal Food Science, vol. 37, pp. 91-94, 2000.

[27] S. Hooda and S. Jood, "Physicochemical, rheological, and organoleptic characteristics of wheat-fenugreek supplemented blends," Nahrung/Food, vol. 47, no. 4, pp. 265-268, 2003.

[28] A. A. Rasool, D. A. Abdulkhaleq, and D. A. Sabir, "Effects of using different percentages of fenugreek flour to improve the sensory, rheological properties and keeping quality in maize dough to produce gluten-free breads," Journal of Agriculture, Science and Technology, vol. 3, pp. 380-384, 2013.

[29] A. Păucean, D. C. Vodnar, V. Mureşan et al., "Monitoring lactic acid concentrations by infrared spectroscopy: a new developed method for lactobacillus fermenting media with potential food applications," Acta Alimentaria, vol. 46, no. 4, pp. 420-427, 2017.

[30] M. Al-Habori and A. Raman, "Pharmacological properties," in Fenugreek: the Genus Trigonella, G. A. Petropoul, Ed., pp. 163-182, Taylor and Francis, London, UK, 2002.

[31] N. Mercan, A. Guvensen, A. Celik, and H. Katircioglu, "Antimicrobial activity and pollen composition of honey samples collected from different provinces in Turkey," Natural Product Research, vol. 21, no. 3, pp. 187-195, 2007. 


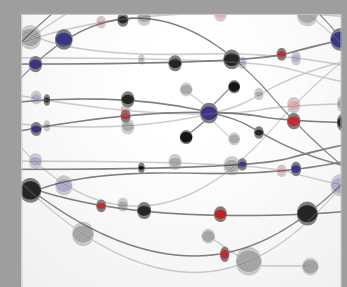

The Scientific World Journal
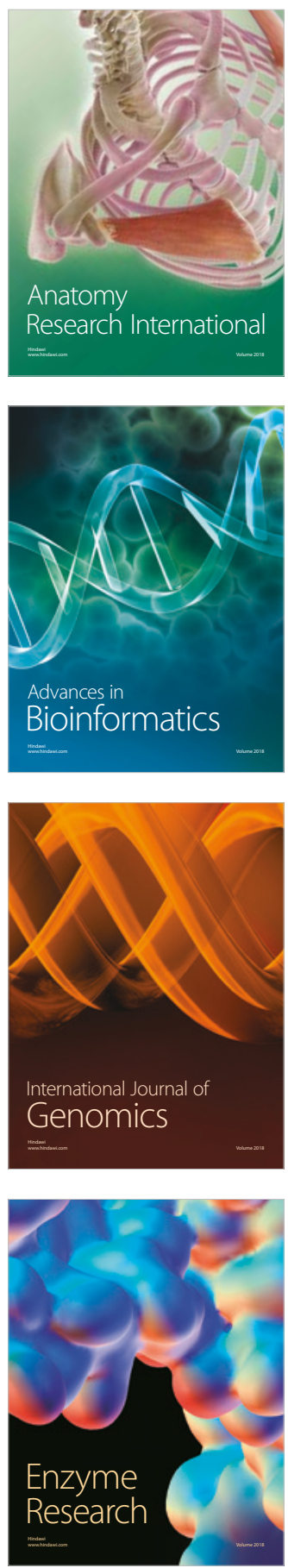
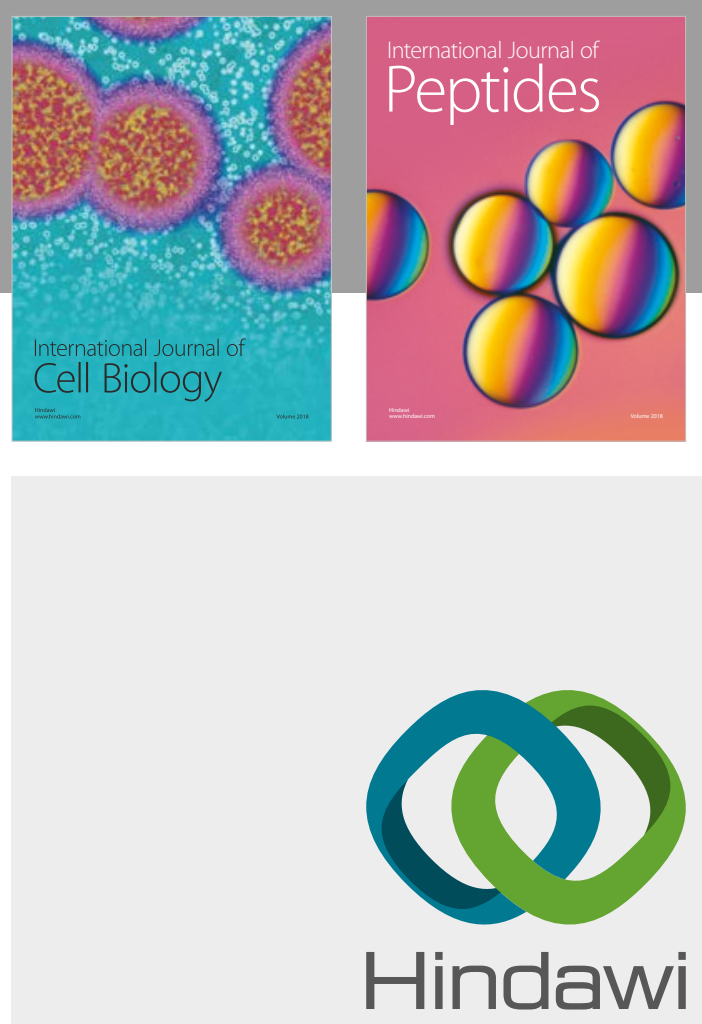

Submit your manuscripts at

www.hindawi.com
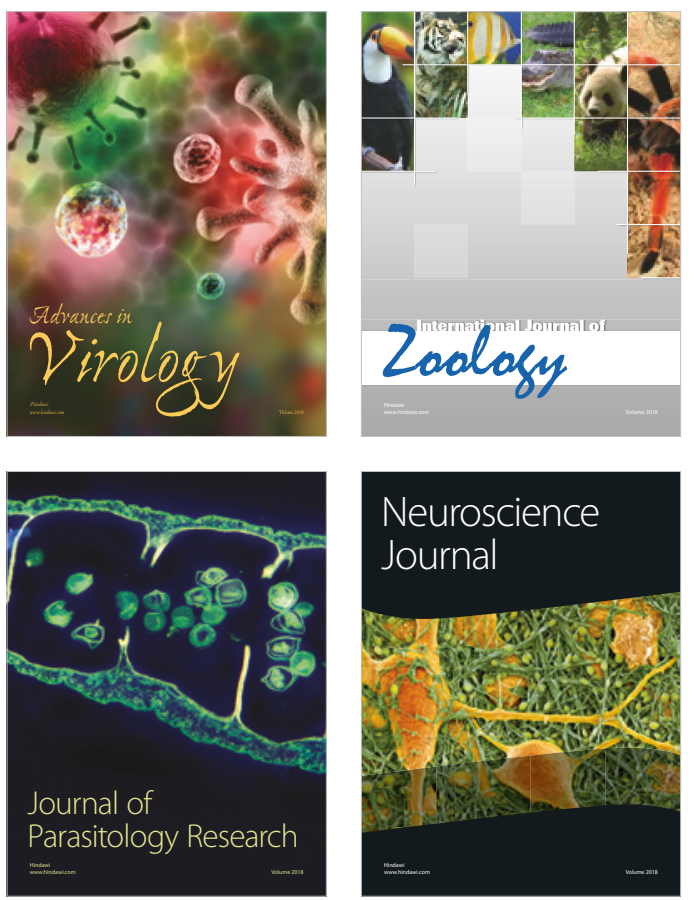
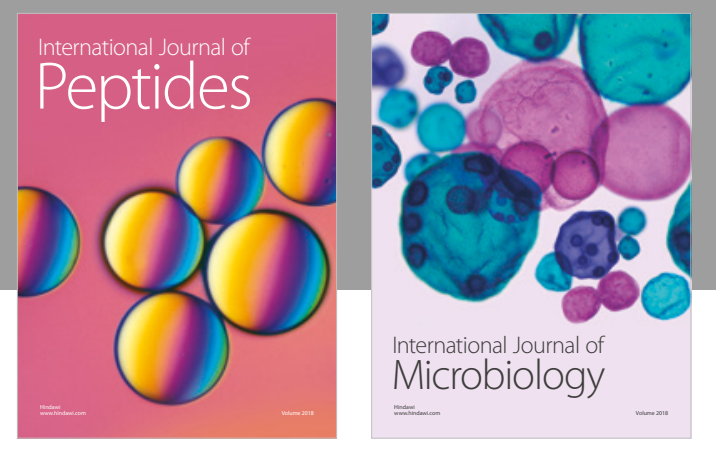

nternational Journal of Microbiology
Journal of
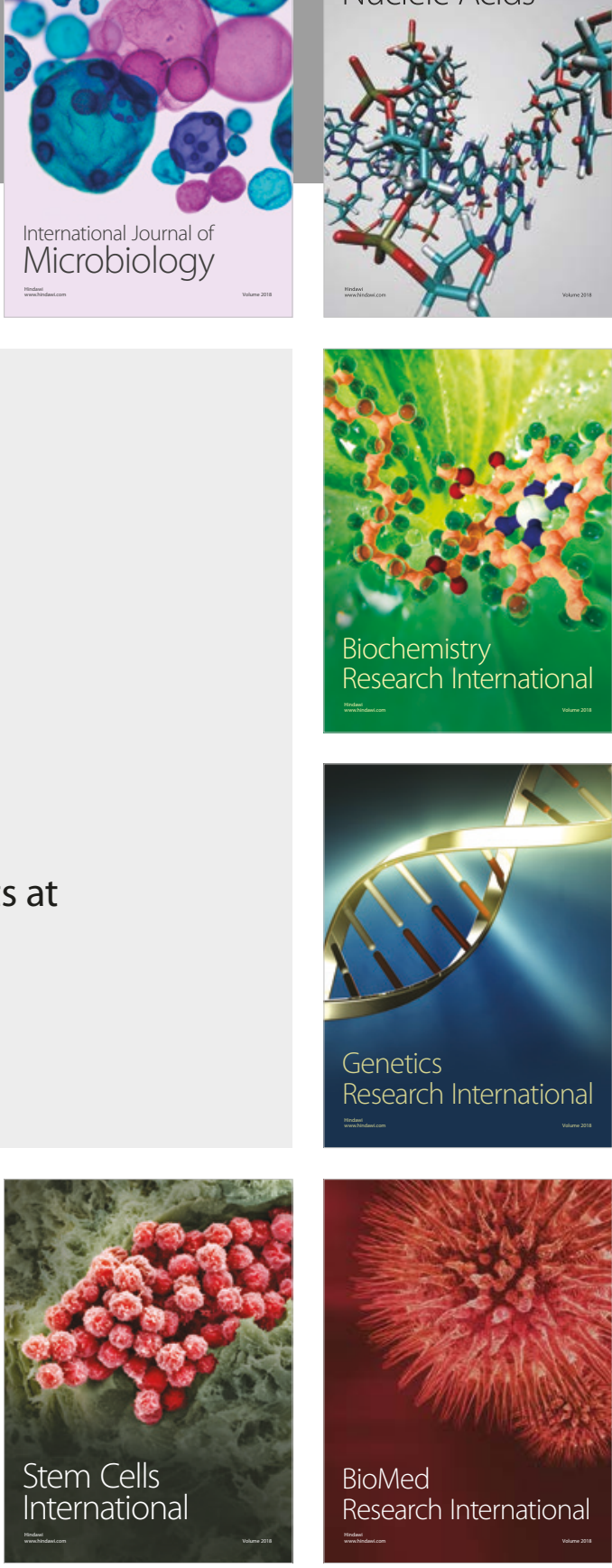
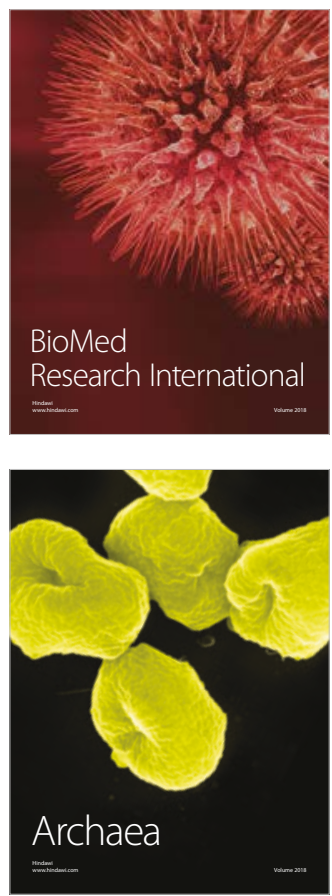